\title{
Vulvar Cancer pN2c TNM Finding v8
}

National Cancer Institute

\section{Source}

National Cancer Institute. Vulvar Cancer pN2c TNM Finding v8. NCI Thesaurus. Code C139616.

Vulvar cancer with lymph node(s) metastasis with extranodal extension. (from AJCC 8th Ed.) 